\title{
Study on strategies of cultivating career self-efficacy of students in Military Academies
}

\author{
Wang Xueren, Ai Chun-an, Yang Yanli, Zhao Jiuling, Liu Guodong \\ Xi'an high-tech graduate school, \\ Shanxi Xi'an, China, 710025 \\ alittlepanda@126.com
}

\begin{abstract}
In allusion to the phenomenon of learning burnout in military academies, a method that raising cadets' studying motivation and enhancing their military qualities by improving their career self-efficacy is proposed. On strategy it can be started from three aspects to improve cadets' career selfefficacy, which consists of optimizing the curriculum system and reforming teaching methods, strengthening cadets' military practice and enhancing the construction of schools' military atmosphere. By this way, the problem of cadets' learning burnout can be effectively resolved.
\end{abstract}

Keywords- learning burnout; career self-efficacy; teaching methods; military practice; construction of atmosphere

\section{EXISTING PROBLEMS DURING CADETS' STUDY ${ }^{[1]}$}

According to the strategy goals of building a informationbased army and winning information-based wars, sticking to building a strong army through science and technology, accelerating composite development of mechanization and Informationization, actively carrying out military training under the condition of information, intensifying training a large number of new military talents with high qualities and actually changing the battle-effectiveness-generated models, are the strategic methods of our army's construction and development in the future. Talents are the base of our army's mightiness and winning. Talents determine the "commanding heights" of future development of army and determine the outcome of future information-based wars. Military academies shoulder the mission of cultivating new military talents with high qualities, but, according to author's research in recent years, it is found that there existing the phenomenon of cadets' learning burnout, which mainly reflects in the lack of motivation and being confused about their own future development. Through interviews it is known that after graduating a majority of cadets have to go to various forces and start from the grass-roots level, so they are lack of control on graduated allocation and cannot effectively plan their career, which leads to lack of motivation for study. There are various reasons for cadets' learning burnout. Thereinto, the specialty of the occupation of being a soldier and special environment in military academies and special model of talents cultivating and allocation is one of the reasons. Therefore, how to improve cadets' motivation and further strengthening their military qualities is a key issue in training cadets at present.

\section{CONCEPT OF CAREER SELF-EFFICACY AND SOLUTIONS TO PROBLEM}

In recent years, with popularizing of higher education and increasing of employment pressure of in China, students is more and more attached importance. Colleges are trying to put vocational guidance throughout the entire education process and focusing on the cultivating students' professional abilities. Cadets need to meet the future requirements and make clear their employment orientation and training goals. A new requirement of training their vocational abilities is put forward, to enable cadets to plan their career more scientifically, possess capacities of selfadaptation and adjustment and dig their own potentials to a much larger extent. Therefore, the cultivation in cadets' vocational abilities can to some extent solve problems such as cadets' learning burnout currently and boost their military qualities.

Self-efficacy is first proposed by Bandura, a United States psychologist in 1977. The so-called self-efficacy means that an individual has faith in his abilities of organization, implementation and meeting a specific achievement. The concept of self-efficacy, an important part of the social cognitive theory, once proposed, attracts the attention of psychologists and is widely used in practice. Bandura believes that, due to the differences between the different areas of activity, abilities and skills they need are also different, so individual self-efficacy for different active tasks are different. Self-efficacy is always linked to a specific domain, so career self-efficacy is a embodiment of self-efficacy in career fields, namely, individuals have faith in whether being competent for tasks or activities related to their jobs ${ }^{[2]}$. The enhancement of career self-efficacy during the vocational education has functions of eliminating job burnout, reducing hesitation about career, increasing employment confidence, improving working attitudes and so on. For cadets, career self-efficacy is mainly embodied in subjective evaluations of the required abilities in completing tasks or relevant activities, as well as the faith or confidence in whether having relevant vocational abilities of their own or not. Therefore, through cultivation of the cadets' career self-efficacy, they can enhance their confidence in developing in army, effectively excite their studying motivation, improve their learning interests and strengthen their military qualities and lay a solid foundation for their development in army in the future. 


\section{STRATEGIES TO IMPROVE CAREER SELF- EFFICACY}

Study ${ }^{[3]}$ reflects that the stronger efficacy the individual have to his own career decision, the higher level the exploration on career-selection and career-planning is, of sexual, the greater the chance of successfully making career decisions is. Therefore, how to improve cadets' career selfefficacy is a key point of this article.

Raising career self-efficacy should be first started from factors affecting the career self-efficacy. Many domestic studies ${ }^{[4-6]}$ show that vocational interest, achievement motivation and attribution style, family support and guidance, as well as some other individual own factors such as a personal view on ability all influence the development of career self-efficacy. Interest refers to the extent of an individual's enjoyment to people, things and objects in the living environment, as well as the positive psychology trend to actively participating in study, career or some other activities. When interests mainly point to career-related activities, it is called career interests, which interacts with career self-efficacy. Achievement motivation refers to a kind of internal drive with which people engaged in valuable work are willing to strive for success. It is unique to humans, and its formation is not related to physiological needs. Atkinson divides achievement motivation into two kinds: one is known as an incentive to strive for success, namely, the pursuit of success and positive emotional orientation brought by success; another is a motivation for avoiding failure, namely, people avoid failure and the negative emotions orientation coming with failure. McClellend found people with high achievement motivation like volunteering their services and undertake pioneering works and dare to make their own decisions at work. Thus, achievement motivation has important effects on individual career self-efficacy. In a word, the effective approaches to cultivation of cadets' career self-efficacy mainly rest with improvement of vocational interest and inspiration of achievement motivation.

In order to improve the career interest cadets and stimulate their achievement motivation, the following can be done:

\section{A. Optimize curriculum system and reform teaching methods}

For students in military academies, studying in class is the primary means of access to education. Optimizing curriculum system and reforming teaching methods, can stimulate students interest in learning, as well as stimulate their career interests, which benefit to enhancing their selfefficacy. To optimizing curriculum system, mainly means to enhance the relevance and operation of course content, in order to let students apply what they have learned. Students can learn special knowledge and skills required for vocational activities during studying, and their career selfefficacy is enhanced.

Optimization of curriculum system also needs a variety of teaching methods to achieve a multiplier effect. In the traditional teaching methods, teachers only focus on the imparting of knowledge but not on training and improving of career capacities, which easily suppresses students' personalities and divergent thinking. Thus it need to fundamentally change the teachers' role in teaching activities, that is to say, from a protagonist and a organizer of teaching in tradition to a guide, a tutor and a toastmaster, to treat students' mind as a handful of torches, constantly emblazing sparks of thinking.

\section{B. strengthening cadets' military practice}

Practice has an important impact on career self-efficacy of the students in military academies. R.Schwarzer also found in research that the accumulation of self-efficacy of specific task from specific tasks and target activities and extend towards the stepwise establishment of efficacy faith in similar activities or activities in different areas. Therefore, strengthening cadets' military practice not only can make cadets to gain practical knowledge, but also through their increasing of practice skills can reach the purpose of improving their career self-efficiency.

To strengthen cadets' military practice, on the one hand, need to increase practice time, on the other hand, need to change practice mode. It can be done on trial to make cadets experience fighters' life, surrogate monitors in the company, be familiar with the most grass-roots command and management and at last consider fulfilling their own roles as surrogate platoon leaders, which can make students gain strong practice of military roles and improve their career self-efficacy.

\section{Enhance the construction of schools' military atmosphere}

Enhancing the construction of schools' military atmosphere is to make cadets find comfort of the environments in army and develop a keen interest on working in army. Military atmosphere construction can be started from the political atmosphere, the cultural atmosphere and the humane atmosphere. To enhance the construction of schools' military atmosphere, quotations or epigraphs of revolutionary tutors and statues or figures of heroes which reflect the nature and tenet of the army and the fine traditions could be placed in the campus, making the campus an "extended classroom" for ideological and political education and students ideology improved imperceptibly. Enhancing the construction of schools' military atmosphere, can fill military academies with songs and laughter and give students a relatively loose cultural atmosphere, with students steeped in the healthy culture. Students in their spare time can take part in cultural creation and performance to enrich cultural life on campus. Enhancing the construction of schools' military atmosphere can make students live in a healthy atmosphere and be close with each other. To optimize the military humane atmosphere should pay attention to the role of Humanities and make personal knowledge and personal morality as models, to make students consummate their personality and purify their soul, and further enhance their career self-efficacy. 


\section{CONCLUSION}

In today's highly competitive era, as countries fiercely contest talents, they also press on with cultivation of talents. To cultivate cadets' career self-efficacy, can both improve their work performance and strengthen stability of cadres, so as to contribute to the elevation of battleeffectiveness. This paper can be a trailblazer, to let more people to focus on cadets' career self-efficacy and study its features, so as to make the ideological and political work more relevant and timely.

\section{REFERENCES}

[1] Zhang Meishan, Xue Linqun. Establish a "People-oriented" Concept of Military Education and Cultivate High-quality New Military Talents [J]. China military science, 2005(6):106.

[2] West point overview [M]. Military Training Department of General Staff of the Chinese people's Liberation Army, 2003:187-190.

[3]Bandura. A Self- efficacy :the Exercise of Control [M]. W.H. Freeman and Company, New York, 1997.

[4]Li Wenming, Liu Fengming. Transition of Teaching Tasks Need to Improve the Level of the Work of Management and Education to Cadets [J]. Naval magazine, 2007:30-32.

[5] Xu Jinhua, Li Changcheng. Delphi method and management forecasting [J]. Journal of binzhou Medical College, 1992(1):85-86.

[6] Dong Tianzhong, Yu Zhiliang. Discussion on Military Education in the Training Mode of "Diversion of training" [J]. Journal of Dalian Naval Academy, 2004(1):74-76. 